\title{
Character Education Values as Reflected In K.H Gholib Struggles of Defending Indonesian Independence in
}

\author{
Lampung \\ Bagas Prakoso Wibowo (Corresponding author) \\ History Education, Graduate School, Yogyakarta State University, Indonesia \\ E-mail: bagasprakoso.2018@student.uny.ac.id \\ Taat Wulandari \\ History Education, Graduate School, Yogyakarta State University, Indonesia \\ E-mail: taat_wulandari@uny.ac.id \\ Johan Setiawan \\ Doctoral Program, Graduate School, Yogyakarta State University, Indonesia \\ E-mail: johansetiawan767@gmail.com
}

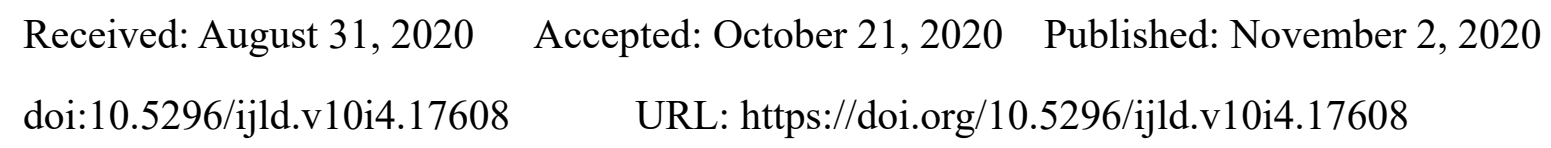

\begin{abstract}
The purpose of this study is to find the values of character education by using material of the Struggle of K.H Gholib in defending Indonesian Independence at the Lampung Residency. The method used is descriptive qualitative research method with library research. The results of this study are briefly elaborated on the biography and struggle of K.H Gholib as a local figure who fought to defend Indonesia's independence at the Lampung Residency. Then the values of character education contained in the material include: religious attitudes, hard work, curiosity, love for the country, nationalism and communicative. These character values can be actualized by students in learning local history in high school. The hope is that students can emulate the figure of a figure from K.H Gholib, especially for those who live in the area of Lampung and apply it to their lives both now and in the future.
\end{abstract}

Keywords: Teaching materials, character values, K.H Gholib 


\section{Introduction}

The phenomenon of deviant behavior especially from students is increasingly alarming. As often expressed both in the mass media, discussions in seminar activities, discussions by educational and social observers. This moral deviation refers to behaviors such as brawls between students, free sex, drugs, cheating, and so on. This is a problem for the nation because if an action is not taken against this moral deterioration, it will affect the survival of the nation (Davies, Grammes, \& Kuno, 2017; Sajanah, 2017).

One way to overcome the various problems above is through education (Fahmy, Bachtiar, Rahim, \& Malik, 2015; Simons \& Cleary, 2006; Wright \& Emich, 2020), because education is the most appropriate media to overcome problems that currently often occur because of its very large role in shaping character (Agboola \& Tsai, 2012; Althof \& Berkowitz, 2006; Rokhman, Syaifudin, \& Yuliati, 2014). One important part of education to embed the concept of character is through Indonesian history subjects.

Indonesian history is one of the subjects that influence the development of insight into national character education (Berkowitz \& Bier, 2005). In the learning of Indonesian history which describes the events collectively from a community or society which is one aspect in the formation of a national personality (Budde \& Weuster, 2017; Cheung \& Lee, 2010). Starting from a collective individual memory which leads to one goal, namely the awareness of national identity through the history of the nation (Ahlerup \& Hansson, 2011).

This is in line with the opinion of Sardiman (2012) that the learning of Indonesian history actually does not merely answer what to teach, but how the learning process is carried out in order to capture and instill value and transform the message behind Indonesia's historical reality to students (Stallions \& Yeats, 2003). This learning process students must master the teaching material, in helping students' personality maturation, so that they are able to respond (Green \& Rechis, 2006), and adapt to the development of increasingly complex national life, and increasingly strong global demands (Lickona \& Davidson, 2005).

Historical Education as an educational program and the field of knowledge does not only provide mere knowledge, but must also foster students to become citizens and citizens who have responsibility for society, love and pride in the nation and state (Novianti, 2017). Thus the subject presented is not limited to material that is knowledgeable but also includes the values attached to it.

Understanding of teachers who consider that Indonesian history lessons are memorized lessons that only rely on memory, so that in teaching teachers only need to transfer material to be conveyed to students. Hasan (2012) argues that this is a major problem in Indonesian history education, which in fact is that teachers pay more attention to the material and discipline of Indonesian history compared to the interests of students (Chou, Yang, \& Huang, 2014).

Teachers must be creative in using learning resources, not just fixing on textbooks as the only learning resource in the learning process. Even though there are more interesting things if the teacher is sensitive to the environment around the students (Berkowitz \& Bier, 2008; 
Romanowski, 2015). In each region, of course there are historical events that occur or there are influential local figures in the community in an area.

The existence of historical events and local figures can be used as a source of learning by teachers in learning local history. For example, the teacher raised a biography of K.H Gholib in learning history with biographical material and his struggle to defend Indonesia's independence in Lampung, specisely in the Pringsewu. This is to provide value education to students (Sajanah, 2017; Tirri, 2009). It is expected that the use of biographies of local leaders in learning local history will be able to introduce these local figures, and the character values possessed by local leaders can be emulated by students. Biography lesson material can be used as material or media to develop cultural values and character of the nation (Ayundari, 2018; Benninga, 2003; Edmonson, Tatman, \& Slate, 2009; Hasan, 2012; Miller, Kraus, \& Veltkamp, 2005).

Students are expected to be able to dive into space and time when K.H Gholib Nasution life began from the journey of his life from childhood until the end of his life, began to study in several Islamic boarding schools until he continued to the city of Mecca. Upon his return from Mecca he became the leader of the Islamic Boarding School and fought in maintaining Indonesia's independence in the Lampung residency. During the journey and struggle, the characters that deserve to be emulated by the younger generation, especially the students who live in Lampung, emerged (Billig, Jesse, \& Grimley, 2008; Bohlin, 2005).

The events contained character education values (O'Sullivan, 2019), this was in line with the 2013 curriculum which emphasized character education. There are 18 values contained in character education, these values include: religious values, tolerance, honesty, discipline, hard work, creative, independent, curiosity, democratic, love for the country, nationality, respect for achievement, friendliness, love of peace, love to read, care for the environment, social, and responsibility (Faza, 2017).

Based on the description of the background above, it is necessary to have local historical material that can instill character values in the learning process (Budde \& Weuster, 2017), one of which is through struggle material K.H Gholib in defending Indonesian independence at the Lampung Residency. This material is to instill the values of character education to students (Thomberg, 2008). It is hoped that this writing can provide a contribution of knowledge especially in learning local history regarding the importance of the educational process in transforming character education values.

\section{Method}

The method used in this study is descriptive qualitative research methods, The descriptive qualitative definition is data in the form of information, a description in the form of prose language is then associated with other data to get clarity on a truth or vice versa, so as to obtain a new picture or load a picture that already exists (Subagyo, 2006). This research is a literature study, data is collected through primary and secondary sources to then conduct content analysis in accordance with the research objectives. 


\section{Result and Discussion}

\subsection{Concept of Character Education}

Education is an effort that is conscious and planned in the process of guidance and learning for individuals so that in its growth to develop into a human who is responsible, creative, independent, knowledgeable, healthy and noble (character). Based on this, there is a need for a learning process that contains character values, so that it is expected that later it can grow the character of the students (Setiawan \& Hadi, 2018; Skaggs \& Bodenhern, 2006).

Speaking of character, character is the basic value that builds a person's personal, formed both because of the influence of heredity and environmental influences, which distinguishes it from others, and is manifested in attitudes and behavior in daily life (Samani \& Hariyanto, 2013). The term character has two meanings. First, if someone behaves badly, cruelly, or greedily, that person will manifest bad behavior. Conversely, if someone behaves honestly, is helpful, surely that person manifests noble character. The two terms of character are closely related to personality, a new person is called a person who has character if his behavior is in accordance with moral rules (Gunawan, 2014; Liu, Xu, Xiao, Liu, \& Li, 2020; Magorinsky \& Taxel, 2005).

According to Wibowo (2013) characters are identical to morals, so characters are universal values of human behavior which include all human activities, both in order to relate to God, with oneself, with fellow human beings, and with the environment, which is manifested in thoughts, attitudes, feelings, words, and developments based on the norms of religion, law, karmic order, culture, and customs.

According to the experts above, it can be concluded that character is a behavior that is in someone's personality in the form of good or in bad behavior, which can differentiate with other people and is done in behavior that appears to be seen by others as well as those who are not seen in everyday life.

From the concept of education and character as mentioned above, the concept of character education emerged. The character education itself according to Wamaungo, where school is the best place to instill character. Wamaungo also explained that one of the main tasks of schools as moral educators is to help students understand the facts and moral attitudes correctly (Wamaungo, 2015). The process of character education is based on cognitive, affective, and psychomotor domains (Listyarti, 2012).

According to Samani (2012) character education is a provision of guidance to students to become fully human with character in the dimensions of heart, mind, and feeling and intention. According to Dharma Kesuma (2011) defines Character education is an attempt to educate children to be able to make wise decisions and practice them in daily life, so that they can contribute positively to their environment.

According to the experts above, it can be concluded that character education is an effort given by a teacher in a school to his students which includes moral education, character education and so on which is expected to be used by a student in his life in daily relationships to always 
do good thing and he knows bad behavior so he can choose which ones are not good in his daily life.

\subsection{Character Education Values}

According to Schutee (2017) Value is an ability that is believed to exist in an object to satisfy humans. The nature of an object that causes to attract someone or group, what is meant by objects or objects here is the value of character education. Kaelan (2008) stated that one type of value is the character value, the character that is meant by character. The character values that will be transformed in the process of learning Indonesian history especially local history include:

1) Religious, that is behavior and attitudes that are obedient in carrying out the teachings of the religion they adhere to, respecting when worshiping other religions and living in harmony with other religious adherents.

3) Honest, that is behavior based on efforts to make himself a person who can always be trusted in words, actions, and actions.

4) Tolerance is the attitude and behavior respecting differences in terms of religion, beliefs, ethnicity, language, race, ethnicity, and opinions consciously and openly. And can live calmly amidst the differences.

5) Discipline, namely habits and actions that are consistent with all applicable regulations or rules.

6) Hard work, namely attitudes and behaviors that show genuine effort in completing various tasks, problems, work, and obstacles in the best way possible.

7) Creative, namely attitudes and behaviors that always reflect the idea of innovation in solving various problems, so that always finding new ways can even create new results better than before.

8) Mandiri, namely attitudes and behaviors that are not dependent on others in completing various tasks and problems. However, this does not mean that collaboration may not be collaborative, but may not throw assignments and responsibilities to others.

9) Democratic, namely attitudes and ways of thinking that reflect equal rights and obligations fairly and evenly between themselves and others.

10) Curiosity, which is a way of thinking, preparing and behaving that reflects curiosity and desire for everything that has been seen, heard, or felt and studied in depth.

11) The spirit of nationalism and nationalism, namely attitudes and actions that place the interests of the nation and state above personal or individual interests and groups.

12) Love the homeland, namely attitudes and behaviors that reflect a sense of pride, loyalty, caring and high appreciation for language, culture, economy, politics and so on, so it is not easy to accept the offer of other nations that can harm the nation itself. 
13) Appreciating achievements, namely an open attitude towards the achievements of others and recognizing one's own shortcomings without reducing the spirit of higher achievement.

14) Communicative, namely open attitude and action towards others through polite communication so that good cooperation between himself and others is created.

15) Peaceful love, namely attitudes and behaviors that reflect an atmosphere of peace, security, calm, and comfort in the presence of themselves in a particular community or community.

16) Loves to read, which is the habit of without coercion to provide time specifically to read various information, both books, journals, magazines, newspapers, and so on, thus giving rise to policies for him.

17) Caring for the environment, namely attitudes and actions that always strive to maintain and preserve the environment around his residence.

18) Social care, namely attitudes and actions that reflect concern for other people and the people in need.

19) Responsibility, namely the attitude and behavior of a person in carrying out their duties and obligations, both those related to oneself, social, society, nation, state and religion (Suyadi, 2015).

Thus the eighteenth character values that must be internalized in schools into all subjects, one of which is through learning Indonesian history which is designed to be active and enjoyable. It is expected through one of the material in local history lessons regarding the values of character education in the struggle of K.H Gholib in maintaining Indonesia's independence at the Lampung Residency which contains character values so that they can be actualized and transformed into students in a learning process, especially in the local history class XI semester 2.

\subsection{Potential Material of Indonesian History and Local History in Character Education}

Indonesian history subjects taught in schools have a strategic goal in shaping the character and dignity of the nation, because they have a sense of nationality and love for the country. The material in learning Indonesian history that is unique and full of value will have the potential to be introduced to students about the nation and its aspirations in the past (Bulach, 2002). It will be able to develop the potential that exists in students to be able to recognize the values of the nation that are fought for, maintained, even developed for the life of the present and the future (Setiawan \& Hadi, 2018).

Indonesian History Material provides information about the success and failure of the nation in answering the challenges of the times. These successes and failures are important lessons to understand. With such material properties, in developing the function of historical education as bank of examples for solving present problems and chartering future action (Wineburg, 2011). Contained by the nation's atmosphere and the limitations of education policies to place knowledge above all else. 
In learning local history that is integrated in Indonesian history lessons, an important function is to learn so that we can recognize our identity as an Indonesian nation. Loss of identity means losing the existence of the nation, the Material of Indonesian History will be able to build the collective memory of students if there is a strong process of identification of historical events learned.

Local history is very important to be taught in learning Indonesian history, this is to introduce local history to each student. Local history as a form of historical writing in a limited scope that includes a particular locality. In this case regarding local history in the Pringsewu area, Lampung Province. A warrior figure who had devoted himself to the Lampung Residency in the days of Dutch colonialism, Japanese occupation and to the end of his life in maintaining Indonesia's independence. He is K.H Gholib, a warrior figure as well as a proud scholar of Lampung.

Through this local history learning, her heroic values became a role model for Lampung people, especially students in high school class XI. These values are transformed into local history learning to shape the character of good students (Ulger, Yigittir, \& Ercan, 2014).

\subsection{Planting Character Education Values in Local History Learning Integrated in Indonesian History}

Local subjects that are integrated in learning Indonesian History which are full of Character Education values can be done through the following steps: First, include selected values of Character Education in the Indonesian History lesson syllabus. Second, include the value of Character Education in the Learning Implementation Plan (RPP) developed by history teachers. The format that has been used by the education unit can be used but enriched by adding a value column.

With the added value, then: (1) Learning objectives and learning materials must be enriched with mastery of values. (2) The learning process (methods and steps) chosen must be appropriate for developing values through the learning process of active students with indirect learning approaches (indirect teaching). (3) Implement learning in accordance with the RPP by paying attention to the learning process for mastering skills and internalizing values (Cheung \& Lee, 2010; Hasan, 2012; Richmond \& Cummings, 2004).

\subsection{K.H Gholib Struggle Material in Defending Indonesian Independence in Lampung}

\subsubsection{Biography K.H Gholib}

K.H Muhammad Gholib was born in the village of Mojosantren Kriyan in 1899. His father was named Kyai Rohani Bin Nursihin and his mother was named Muskiti. The educational background of K.H Gholib began with studying the Al-Qur'an with his mother, then when he was six years old he studied with Kyai Ali in Mojosantren to study Al-Qur'an, the science of jurisprudence, monotheism, morals and others. After studying with Kyia Ali, K.H Glolib also studied with several theologians in East Java including K.H Hasyim Asyari in Tebuireng and K.H Kholil in Bangkalan.

As an adult K.H Gholib married a woman named Sya'iyah who was a descendant of 
aristocracy in Central Java. During his marriage to Sya'iyah, K.H Glolib was not blessed with children. So he adopted three children at once from his uncle named Zamjali, Rubaidah and Romlah.

K.H Gholib and his wife decided to wander in order to preach Islam outside of Java. According to him in Java, there have been many theologians who spread Islam, Singapore was chosen as a mission in preaching Islam. Basically K.H Gholib is good at socializing and full of authority, so there he had no difficulty in carrying out the mission of da'wah Islamiyah.

In 1905 the first nationalist movement emerged in Indonesia, the movement was named Sarekat Dagang Islam. The movement seemed to be the pioneer of the establishment of another nationalist movement that had a mission and aim to make Indonesia free from the shackles of colonialism (Nasution, 2018).

This movement is generally led by young students and scholars. On the basis of this movement K.H Gholib returned to Indonesia and stayed in Pringsewu to join in the struggle to bring change to the people of Indonesia.

In the era around 1930, K.H Gholib founded a boarding school, whose main purpose was to print students who were smart in the religious field as well as formal education. The first education formed was a madrasa with 100 students, occupying buildings made of gribik and grounded.

The Dutch who knew the existence of the K.H Gholib boarding school, for them this was a threat that could endanger the Dutch position in Pringsewu. For this reason, the Netherlands always closely monitors the activities undertaken by K.H Gholib in his pesantren. Although always monitored, K.H Gholib and his religious teachers continued to broadcast Islam and develop their Islamic boarding school.

Until 1942, Japan succeeded in controlling Indonesia after the supreme commander of the Dutch government surrendered unconditionally to Japan. Automatically, Japan replaced the Dutch position in Indonesia. At first the Indonesian people welcomed the arrival of the Japanese army with great feeling for freeing the Indonesian people from the Dutch colonialism. In reality Japan is not much different from other imperialist countries like the Netherlands.

In Lampung, many Dutch heritage education buildings were closed, including Islamic boarding schools. The Japanese government in Pringsewu came to the K.H Gholib boarding school, they asked that his boarding school be closed, but K.H Gholib refused and the Japanese finally detained K.H Gholib. While in detention, K.H Gholib was told to teach his students to worship the sun and recognize Tenno Hei Ka as the representative of God.

This request was refused firmly by K.H Gholib, for his efforts in diplomacy finally Japan released K.H Gholib on condition that his students should be included in Japanese military education and KH. Gholib was appointed as an advisor to the Islamic Religion in Pringsewu by the Japanese government, until Japan lost the war at the hands of the Allies in 1945 (Imran, 
2001).

Japan's defeat against these allies, Indonesia which was in a state of power vacuum Soekarno declared Indonesia's independence in Jakarta in 1945. When Indonesia was independent, the Dutch wanted to re-colonize Indonesia by carrying out military aggression into Indonesia. K.H Gholib participated in the struggle to maintain Indonesian independence until 1949 he was shot dead by Dutch soldiers.

3.5.2 Traces of the Struggle of K.H Gholib in Indonesian Independence from the Lampung Residency

KH. Gholib's struggle in maintaining Indonesian independence in Lampung by taking up arms, began during the second military aggression carried out by the Dutch army in several regions in Indonesia in order to re-colonize the Indonesian nation, including in Lampung.

The Netherlands entered the Lampung region by sea to Lampung Bay. The arrival of the Dutch army was immediately greeted by resistance by the ALRI unit (the TNI Section), but this resistance was unable to frustrate the Dutch, who eventually succeeded in controlling several important areas such as Telukbetung and Tanjung Karang (the central government of the Lampung Residency). For this reason, many Indonesian fighters took refuge in the home of one of the leading clerics in the Pringsewu area, named K.H Gholib, to arrange battle tactics.

Therefore with this incident, K.H Gholib joined the movement to fight for the defense of the nation and state of Indonesia. Armed with military training during the Japanese occupation. K.H Gholib who has a high sense of nationalism and is a great and influential cleric can easily ignite the enthusiasm of the people to join in the struggle together with the TNI in order to expel the Dutch who want to regain power in Indonesia (Nyamat, Warto, \& Djono, 2020). Although using simple weapons, K.H Gholib was not afraid of dealing with the Dutch army.

K.H Gholib's forces joined the Red Garuda troops under the leadership of Captain Alamsyah who was part of the TNI to carry out attacks and succeeded in recapturing Gedongtataan which was previously controlled by the Dutch on January 15, 1949. This success forced the Dutch to retreat to Tanjungkarang. Not long after, the Dutch troops counterattacked. TNI troops and K.H Gholib who lost in terms of technical and equipment escaped to Pringsewu.

Knowing that the fighters were hiding in the Pringsewu area, the Dutch moved towards Pringsewu. They want to control the Pringsewu area which is the center of the gathering of Indonesian fighters. Hearing this, K.H Gholib and his Hezbollah troops advanced to confront the Dutch at Gadingrejo, because they were outnumbered and finally K.H Gholib and his troops withdrew and destroyed a bridge in Bulukarto to prevent Dutch troops from reaching Pringsewu.

This effort succeeded in hindering the Dutch troops to Pringsewu, finally the Dutch troops took the sea route to get to Pringsewu. On March 11, 1949 Dutch troops successfully landed in Kotaagung and began attacking Pringsewu with the strength of land and air forces. Ground 
troops invaded using tanks, while air forces fired on the defenses of the warriors blindly and in the end Pringsewu fell into Dutch hands on March 13, 1949 (Hutama, Wakidi, \& Arif, 2015).

Pringsewu, which had been successfully controlled by the Dutch, made TNI and K. Gholib troops cross the Way Sekampung river to find a hiding place. K.H Gholib continued to evacuate and move around until he finally settled in a village called Sinarbaru. K.H Gholib after a tiring struggle, made him sick and had to be treated. Along with time, the news of its existence was known by Dutch troops. Dutch troops detained him for 15 days and was finally shot to death.

\subsection{Character Education Values in the Material of Struggle K.H Gholib in Defending Indonesian Independence in Lampung}

Referring to the material on the Struggle of K.H Gholib in defending Indonesian Independence in Lampung and was associated with eighteen values of character education. Then the character values contained in the material are religious, hard work, curiosity, love for the country and nationalism. The following is a description of the character values contained in the material in the Struggle of K.H Gholib in defending Indonesian Independence in Lampung, among others.

\subsubsection{Religious}

The religious attitude was shown by K.H Gholib since he was a child studying religion at Islamic boarding schools in Pringsewu and several other areas until finally he studied in Mecca. He has a strong desire to become a person who is religious and wants to preach to the community to invite to do good.

\subsubsection{Hard Work}

Being a leader of an Islamic Boarding School and leading a struggle organization namely Laskar Hizbullah requires an effort to work hard to achieve the goal. A hard worker has a behavior that shows an earnest effort in completing various tasks, problems, work, etc. with the best.

\subsubsection{Curiosity}

Curiosity the great K.H Gholib has guided him to study from various Islamic boarding schools in Indonesia and to the city of Mecca. This shows that he has great curiosity in exploring and learning a science.

\subsubsection{Love the Country}

The love attitude of the motherland which is owned by K.H Gholib We can see K.H Gholib in his struggle to defend Indonesia's independence at the Lampung Residency. When the Dutch military aggression II took place in 1949, he led the resistance against the Dutch army with his troops, the Laskar Hizbullah, until finally he died in the war. This shows that he is in love with his native land, Indonesia. Not willing to be re-colonized by the foreign nation. 


\subsubsection{The Spirit of Nationalism}

As a scholar who has a high position, he may not defend the interests of the people of Pringsewu and the people of Lampung are free from the shackles of the colonizers. But the attitude of the national spirit possessed by K.H Gholib. We can see K.H Gholib with his attitude and actions that are willing to sacrifice himself in emphasizing his birthplace.

\subsubsection{Communicative}

K.H Gholib has good communication skills, this was proven when he was appointed by Japan as an advisor to the Islamic Religion in Pringsewu. During the second Dutch military aggression in 1949, he worked closely with the TNI forces to confront the Dutch forces together. Thanks to his expertise in communication, therefore good cooperation was established between him (Hezbollah forces and TNI troops).

\section{Conclusion}

Character education is a process of giving guidance that refers to the character values given by the teacher to students to be fully human, characterized by good character. The values contained in character education are religious, tolerance, honesty, discipline, hard work, creative, independent, curiosity, democratic, homeland love, nationality, respect for achievement, friendliness, peace of mind, love to read, caring for the environment, social, and responsibility. Thus the value of character education that is internalized in schools into the subject is through learning local history that is integrated in Indonesian history. Indonesian history subjects taught at school have a purpose to shape the character and dignity of the nation, because it has a sense of nationality and love for the country. Also through learning local history, her heroic values became role models for Lampung people, especially students in high school class XI. These values are transformed into local history learning to shape the character of good students. Local subjects that are integrated in learning Indonesian History can be done through the following steps: First, include selected values from Character Education in the Indonesian History lesson syllabus. Second, enter the value of Character Education in the Learning Implementation Plan (RPP). Third, carry out learning in accordance with the RPP by paying attention to the learning process for skills mastery and value internalization. Struggle Material K.H Gholib in maintaining Indonesia's independence at the Lampung Residency in the local history lesson of class XI in semester 2, consisted of biographies of his life and his struggle to fight the Dutch until his death in 1949. Referring to the material on the Struggle of K.H Gholib in defending Indonesian independence at the Lampung Residency and was associated with eighteen character values set by the Ministry of National Education through the Curriculum Research and Development Center. Then the character contained in the material of the Struggle of K.H Gholib in maintaining Indonesia's independence at the Lampung Residency included: religious, hard work, curiosity, love for the country, nationalism, and communicative.

\section{References}

Agboola, A., \& Tsai, K. C. (2012). Bring Character Education Into Classroom. European Journal of Educational Research, 1(2), 163-170. https://doi.org/10.12973/eu-jer.1.2.163 
Ahlerup, P., \& Hansson, G. (2011). Nationalism and Government Effectiveness. Journal of Comparative Economics, 39(3), 431-451. https://doi.org/10.1016/j.jce.2011.05.001

Althof, W., \& Berkowitz, M. W. (2006). Moral Education and Character Education: Their Relationship and Roles in Citizenship Education. Journal of Moral Education, 35(4), 495-518. https://doi.org/10.1080/03057240601012204

Ayundari, L. (2018). Relevansi Nilai-nilai Perjuangan K.H. Masjkur dalam Pembelajaran Sejarah Berbasis Pendidikan Karakter bagi siswa MA di Malang. Jurnal Sejarah Indonesia, 1(1), 40-52. https://doi.org/10.17977/um033v1i120180400

Benninga, J. S. (2003). The Relationship of Character Education Implementation and Academic Achievement in Elementary School. Journal of Research in Character Education, 1(1), 19-32. Retrieved from https://files.eric.ed.gov/fulltext/EJ753972.pdf

Berkowitz, M. W., \& Bier, M. (2005). Character education: Parents as partners. Educational Leadership, 63(1), 64-69. $\quad$ Retrieved from https://www.researchgate.net/publication/285799342.

Berkowitz, M. W., \& Bier, M. C. (2008). Research-based character education. Annals o the American Academy of Political \& Social Science, 591, 72-85. https://doi.org/10.1177/0002716203260082

Billig, S. H., Jesse, D., \& Grimley, M. (2008). Using Service Learning to Promote Character Education in a Large Urban District. RMC Research, Denver. Journal of Research in Character Education, 6(1), 21-34. Retrieved from https://eric.ed.gov/?id=EJ753972

Bohlin, K. E. (2005). Teaching Character Education through Literature: Awakening the Moral Imaginations in Secondary Classrooms. Oxon, New York: Routledge Falmer. https://doi.org/10.4324/9780203299838

Budde, J., \& Weuster, N. (2017). Class Council Between Democracy Learning and Character Education. Journal of Social Education, 16(3), 52-61. https://doi.org/10.2390/jsse-v16-i3-1593

Bulach, C. R. (2002). Implementing a character education curriculum and assessing its impact on student behavior. The Clearing House, 76(2), 79-93. https://doi.org/10.1080/00098650209604954

Cheung, C. K., \& Lee, T. Y. (2010), Improving Social Competence through character education. Evaluation and Program Planning, 33, 255-263. https://doi.org/10.1016/j.evalprogplan.2009.08.006

Chou, M., Yang, C., \& Huang, P. (2014). The Beauty of Character Education pn Preschool Children's Paren- Child Relationship. Procedia-Social and Behavioral Sciences, 143, 527-533. https://doi.org/10.1016/j.sbspro.2014.07.431

Davies, I., Grammes, T., \& Kuno, H. (2017). Character is the Continuously Defined Way of How Man Relates to the World. Journal of Social Science Education, 16(3), 2-7. https://doi.org/10.1016/j.sbspro.2014.05.197

Edmonson, S., Tatman, R., \& Slate, J. R. (2009). Character Education: A Critical Analysis. International Journal of Educational Leadership Preparation, 4(4), 1-20. https://doi.org/10.1016/j.appdev.2005.12.002 
Fahmy, R., Bachtiar, N., Rahim, R., \& Malik, M. (2015). Measuring Student Perceptions to Personal Characters Building in Education: An Indonesian Case in Implementing New Curriculum in High Scholl. Procedia-Social and behavioral Sceinces, 211, 851-858. https://doi.org/10.1016/j.sbspro.2015.11.112

Faza, A. (2017). Pengajaran Sejarah sebagai Media Penanaman Wawasan Kebangsaan, Jurnal Wiyanata, 8(2), 1-11. http://dx.doi.org/10.23887/jjps.v7i3.12551

Green, V. A., \& Rechis, R. (2006). Children's cooperative and competitive interactions in limited resource situations: A literature review. Applied Developmental Psychology, 27, 42-59. https://doi.org/10.1016/j.appdev.2005.12.002

Gunawan, H. (2014). Pendidikan Karakter: Konsep dan Implementasi. Bandung: Alfabeta.

Hasan, S. H. (2012). Pendidikan Sejarah Indonesia: Isu dalam Ide dan Pembelajaran. Bandung: Rizqi Press.

Hasan, S. H. (2012). Pendidikan Sejarah untuk Memperkuat Pendidikan Karakter. Jurnal Paramita, 22 (1), 81-95. https://doi.org/10.15294/paramita.v22i1.1875

Hutama, R., Wakidi., \& Arif, S. (2015). Perjuangan K.H Gholib dalam mempertahankan Kemerdekaan Indonesia tahun 1949. Jurnal Pendidikan dan Penelitian Sejarah, 3(1), 1-12. Retrieved from http://jurnal.fkip.unila.ac.id/index.php/PES/article/view/7779

Imran, A. (2001). Sejarah Pembentukan Provinsi Lampung. Proyek Kerjasama Balitbang dan Provinsi Lampung Lembaga Penelitian Unila.

Kaelan, M. S. (2008). Pendidikan Pancasila. Yogyakarta: Paradigma.

Kesuma, D. (2011). Pendidikan Karakter: Kajian Teori dan Praktik di Sekolah. Bandung: Remaja Rosdakarya.

Lickona, T., \& Davidson, M. (2005). Smart and good high schools: Integrating excellence and ethics for success in school, Work and beyond, Character education partnership. Washington DC.

Listyarti, R. (2012). Pendidikan Karakter dalam Metode Aktif, Inovatif \& Kreatif. Jakarta: Penerbit Erlangga

Liu, L., Xu, L., Xiao, X., Liu, L., \& Li, Y. (2020). Positive influence of peer's interpersonal character: The moderating role of children's and peers' social status. Journal of Adolescence, 79, 157-172. https://doi.org/10.1016/j.adolescence.2020.01.003

Magorinsky, P., \& Taxel, J. (2005). The discourse of character education: Culture wars in the classroom. Mahwah, NJ: Lawrence Erlbaum https://doi.org/10.4324/9781410613011

Miller, T. W., Kraus, R. F., \& Veltkamp, L. J. (2005). Character education as a prevention strategy in school-related violence. Journal of Primary Prevention, 26, 455-466. https://doi.org/10.1007/s10935-005-0004-X

Nasution, S. N. (2018). Spirit of Nationalism, Education and Moral Religion. International Journal of Linguistics, Literature and Culture, 5(1), 24-31. https://doi.org/10.21744/ijllc.v5n1.478

Nyamat, M., Warto, \& Djono. (2020). Implementation of nationalism values of KH. Hasyim Asya'ri Struggle in Indonesian History Learning at Maarif 1 Kebumen Vocatiobal High 
School, 3(2), 48-61. https://doi.org/10.37500/IJESSR.2020.3026

Novianti, N. (2017). Teaching Character Education to College Using Bildungsromans. International Journal of Instruction, 10(4), 255-272. https://doi.org/10.12973/iji.2017.10415a

O'Sullivan, S. (2019). Books to live by: Using children's literature for character education. The Reading Teacher, 57, 640-645. Retrieved from https://www.jstor.org/stable/20205410

Richmond, A. S., \& Cummings, R. (2004). In support of the cognitive-developmental approach to moral education: A response to David Carr. Journal of Moral Education, 33, 197-205. https://doi.org/10.1080/0305724042000215230

Rokhman, F., Syaifudin, A., \& Yuliati (2014). Character Education For Golden Generation 2045 (National Character Building for Indonesian Golden Years. Procedia-Social and behavioral Sceinces, 141, 1161-1165. https://doi.org/10.1016/j.sbspro.2014.05.197

Romanowski, M. (2015). Through the Eyes of Teachers: High School Teachers' Experiences With Character Education. American Secondary Education, 34(1), 6-23. Retrieved from https://www.jstor.org/stable/41064559

Sajanah, A. T. (2017). Biografi KH. Noer Ali Materi Ajar dan Nilai-Nilai Karakter dalam Pembelajaran Sejarah Lokal dalam. Proseding seminar nasional: Sejarah Lokal tantangan dan masa depan. Malang: FIS UMM.

Samani, M. (2012). Pendidikan Karakter. Bandung: PT. Remaja Rosdakarya

Samani, M., \& Hariyanto. (2013). Konsep dan Model Pendidikan Karakter. Bandung: PT Remaja Rosdakarya.

Sardiman, A. M. (2012). Pembelajaran Sejarah dan Pembangunan Pendidikan Karakter Bangsa dalam Pendidikan Sejarah Untuk Manusia dan Kemanusiaan. Jakarta: Bee Media.

Schutee, K., Zimmermann, F., \& Koller, O. (2017). The role of domain-specific ability self-concepts in the value students attch to school. Learning and Individual Differences, 56, 136-142. https://doi.org/10.1016/j.lindif.2016.10.003

Setiawan, J., \& Hadi, R. S. (2018). Nilai-nilai Pendidikan Karakter dalam Materi Sejarah Kebangkitan Nasional Indonesia. Jurnal Sejarah dan Budaya, 12(1), 39-48. http://dx.doi.org/10.17977/um020v12i12017p39

Simons, L., \& Cleary, N. (2006). The influence of service learning on student's personal and $\begin{array}{llll}\text { social development. } & \text { College } & \text { Teaching, } & \text { 54(4), }\end{array}$ https://doi.org/10.3200/CTCH.54.4.307-319

Skaggs, G., \& Bodenhern, N. (2006). Relationships between implementing character education, student behavior, and student achievement. Journal of Advanced Academics, 18, 82-114. https://doi.org/10.4219/jaa-2006-345

Stallions, M. A., \& Yeats, K. (2003). Enhancing Character Education for Tomorrow's Teacher, Today: A Connected Learning Partnership Model. Florida Association of Teacher Educators Journal, 1(3), 250-260. https://doi.org/10.26737/jetl.v4i2.960

Subagyo, J. P. (2006). Metode Penelitian: Dalam Teori dan Praktek, Jakarta: Rineka Cipta

Suyadi. (2015). Strategi Pembelajaran Pendidikan Karakter. Bandung: PT Remaja Rosdakarya. 


\section{Macrothink}

International Journal of Learning and Development

ISSN 2164-4063 2020, Vol. 10, No. 4

Thomberg. R. (2008). Values education as the daily fostering of school rules. Research in education, 80, 52-62. https://doi.org/10.7227/RIE.80.5

Tirri, K. (2009). Character Education and Giftedness. High Abilit Studies, 20(2), 117-119. https://doi.org/10.1080/13598130903358493

Ulger, M., Yigittir, S., \& Ercan, O. (2014). Secondary School Teachers' Beliefs on Character Education Competency. Procedia-Social and Behavioral, 131, 442-449. https://doi.org/10.1016/j.sbspro.2014.04.145

Wamaungo, J. A. (2015). Mendidik untuk Membentuk Karakter: Bagaimana Sekolah dapat Memberikan Pendidikan tentang Sikap Hormat dan Bertanggung Jawab. Jakarta: Bumi Aksara.

Wibowo, A. (2013). Manajemen Pendidikan Karakter Di Sekolah. Yogyakarta: Pustaka Pelajar.

Wineburg, S. (2001). Historical Thinking and Other Unnatural Acts: Charting the Future of Teaching the Past. Philadelphia: Temple University Press.

Wright, T., \& Emich, K. J. (2020). Character in crisis: The benefits of the 3-H approach to character development. Organizational 1-10. https://doi.org/10.1016/j.orgdyn.2020.100755

\section{Copyright Disclaimer}

Copyright for this article is retained by the author(s), with first publication rights granted to the journal.

This is an open-access article distributed under the terms and conditions of the Creative Commons Attribution license (http://creativecommons.org/licenses/by/3.0/). 